\title{
TO GO TO SCHOOL OR NOT? - USE OF SOCIAL COGNITIVE CAREER THEORY TO UNDERSTAND NON-PARTICIPATION OF RURAL GIRLS IN FORMAL SCHOOLS
}

\author{
Nidhi Singh \\ Independent Researcher, New Delhi, India
}

\begin{abstract}
Majority of out of school girls are located in rural areas of the world. There exist many challenges both at the demand side and the supply side which keep them away for school. This essay conducts a literature review of all such challenges and uses the Social Cognitive Career Theory to identify possible reasons for non-participation of girls in schools in rural areas. The review finds that girls in rural areas suffer from low self-efficacy and possess non-ambitious outcome expectations with respect to educational and occupational pursuits in life, which also lead to low goal settings. The main reasons for this are traditional gender role expectations from girls by community, economic condition of a family, absence of positive role models amongst others. Possible intervention points are then suggested with the hope that researchers will conduct in-depth research into challenges of these girls which is used by policy makers in the near future.
\end{abstract}

Keywords: rural, education, girls, cognitive theory

\section{INTRODUCTION}

Education is a human right, enshrined in the Universal Declaration of Human Rights and the United Nations Convention on the Rights of the child (Unesco.org, 2015). In light of this declaration, the World Bank put forward the Millennium Development Goal (MDG) 2 of achieving universal primary education. The world has made impressive strides in achieving this goal. Countries such as Bangladesh and Nepal have achieved 92\% (2010) and $98 \%$ (2013) net primary enrollments (Data.worldbank.org, 2015). Bhutan has also achieved $88 \%$ enrollment of primary school age children in 2008. India has also achieved 93\% (2011) enrollment at the primary school level (Data.worldbank.org, 2015).

However, most recent data by UNESCO Statistical Institute states that 58 million children are still out of school throughout the world (Uis.unesco.org, 2015). Other backdated figures, by Lewis and Lockheed (2006) further present that around 60 million girls are 'out of school'. Majority of these girls live in rural areas all around the world (Uis.unesco.org, 2010). What is keeping these girls away from school? Much evidence, illuminating reasons of non-participation of girls in school, is available. This essay presents a detailed literature review of the same. The next step will be to use the Social Cognitive Career Theory (SCCT) to structure the literature review for better understanding of issues at hand, to look for possible solutions and to provide way for future research in the area.

SCCT, grounded in and derived from Bandura's social cognitive theory is an appropriate lens to understand non-participation, low enrollment of girls in rural areas for the fact that the theory puts emphasis on dynamic nature of personal mechanisms which influence an individual to take decisions. This study is useful to understand what drives the girls and the community to opt out of school and make certain career choices. SCCT provides a framework to delve 
in deeper in the minds of the community and girls and why they take certain decisions and make certain career choices. Perun and Bielby (1981) propose that women's educational attainment should be viewed in a life-span perspective and should also incorporate social structure restrictions prevalent in the society. The SCCT solves this purpose and presents the role of barriers related to social structure restrictions in girls' educational attainment and how these influence her mind.

This essay is divided into four parts. The first section explains the SCCT theoretical construct. Then, the second section presents a literature review of the reasons for non-participation of girls in schools. The third section synthesizes the information and breaks it into components listed under SCCT. The last section puts forward possible solutions/interventions that would help policy makers in designing programmes targeted towards girls in rural areas. This section also presents the scope for further research briefly.

\section{LIMITATIONS OF THE STUDY}

This study is a purely secondary study and hence the reader may find some missing information during the course of reading this piece. This will be highlighted where such a condition in encountered.

\section{Social Cognitive Career Theory}

The original social cognitive theory, introduced by Albert Bandura in 1986 provides a framework for understanding and predicting human behavior (Bandura, 1986). The framework has been used in fields of politics, school achievement and health among many others. It is based on two core constructs: self-efficacy and outcome expectancies. Self-efficacy is concerned with an individual's belief about his/her capabilities to perform a task and outcome expectancies are concerned with beliefs around consequences of an action (Luszczynska \& Schwarzer, 2005). Anchored in this general theory, the Social Cognitive Career Theory (SCCT) provides a method to understand processes, through which individuals form interests, make choices and achieve varying levels of success in educational pursuits. There are three basic tenets of SCCT - (1) selfefficacy (2) outcome expectations and (3) goals (Lent, Brown \& Hackett, 1994). However, Lent, Brown \& Hackett (2000) express their discomfort towards the fact that environmental factors have not been given the importance they deserve. Most of the research has been focused on cognitive person variables - self efficacy, outcome expectations and goals. They divide environmental factors into two categories - distal and proximal. Distal, background contextual factors consists of factors that affect learning experiences which further give rise to selfefficacy and outcome expectations. Examples of these include the presence of relevant role models and support received for engaging in academic activities. Proximal category on the other hand consists of factors that play an important role during active phases of educational or career decision making. However, for simplicity, both of these have been clubbed under one head called - barriers (explained later).

An individual builds self-efficacy via four methods: (1) by observing their own success or personal performance, (2) by watching others, whom they emulate, (3) by receiving encouragement of others and lastly (4) by judging their physiological stress levels in a particular situation (Bandura, 1977). Gibbons (2004) presents an example of a girl Lisa who believes that she will not be able to attend college because of her poor grades in math. This belief was formed by statements made by her teacher that she will be unable to pass math next year. She also feels stupid in front of her high performing classmates. Lisa, in this case is driven by her performance in math class and interaction with fellow classmates and her teacher which led to formation of a low/negative self-efficacy regarding her ability to join college in the next year.

This paper uses SCCT model as theorized by Lent, Brown \& Hackett (1994), with a focus on six variables - barriers, self-efficacy, outcomes expectations, interests, goals and actions. Figure 1 below depicts the simplified SCCT model used for this essay. Person inputs, distal and proximal environmental factors in SCCT as explained by Lent, Brown \& Hackett (1994) have been grouped together - called barriers in this essay. This is due to lack of specific information for environmental factors in detail. A detailed qualitative review of girls in rural areas would provide the necessary insights required for explanation of all the factors. A simplified version of SCCT is used here. Various forms of barriers 
influence self-efficacy and outcome expectations in girls. Their perspective of self-efficacy and outcome expectations defines the line of actions the girls take for themselves. This is not a linear process as selfefficacy and outcome expectations have an influence on interests, goals and actions.

\section{Challenges in girls' education in rural areas}

Rural areas of developing and under-developing nations have been struggling to increase enrollments of girls. However, post the formation of Millennium Development Goals (MDGs) in the year 2000; these countries have seen massive improvement in girl enrollment rates. Now, the Sustainable Development Goals (SDGs) have provided more impetus to the goal of educating the girl child. There still lie considerable obstacles in this path. The next few paragraphs will focus on identification of such obstacles which then will be the foremost step should be to understand her life circumstances and behavior $\&$ perspective of people around her.

Researchers have conducted in-depth studies in various countries illuminating reasons for nonparticipation of girls in schools. It has been observed that participation of girls is highest in primary stage, keeps decreasing through secondary and finally the lowest participation is observed in tertiary stages. Girls are pulled out of school as they grow older due to various reasons encountered within families and schools. Stromquist (1989) identifies 'family-related factors as - economic condition of household, cultural and social factors, parental aspirations; and 'schoolrelated' factors as - distance to school, school infrastructure and curriculum and teaching practices.

Investigation of interdependence between gender and educational attainment by Beutal and Axinn (2002) in rural Nepal found gender differences in educational attainment because of the perceived adult-role of women in their society. The role requires them to get married, bear children and perform domestic duties/farm labour which is in conflict with the role (career oriented) that a woman is expected to adhere to after attaining education. Moreover, parents also do not find it lucrative to spend on the education of their daughters as post-marriage they join another household. Their earnings (if any) will benefit in-laws and not natal families. Similar findings were captured by Hannum (2003) during the times of education decentralization in rural China during the early 1990s. She also posits that children's schooling decisions are an element of family survival strategies. Poverty stricken households look for investing in areas where they can receive maximum return on investment later, in turn favouring son's education. Moreover, education is rightly perceived as promoting interaction with a larger world, but which is fit only for men and not for women. Economic calculation of sending children to school saw investment in boys' education as a better proposition as compared to investment in girls' education. Girls are required extensively in domestic work and hence paying their fee for sending them to school incurs a double cost - of the labour cost and fee paid (Johnson, 1993).

Tibenderana (1945) in his review of Girls' Education in Native Administration schools in Nigera, points out similar reasons for girls not joining schools. The early all-girl schools in Nigera were built for daughters of the then ruling class. When it came to expanding participation from other social classes, parents from other classes were not keen to send their girls to such schools as they did not want them to 'mix' with the ruling class. Distance was also quoted as one of the other reasons. Jones (1980) also expressed same views with addition of a few more, such as, objections to co-educational classes, irrelevance of education for girls and protection of honor for adolescent girls, for non-participation of girls in rural Tunisia. Traveling long distances to school can prove to be physically abusive and sometimes fatal for the girls in rural areas. Johnson (1993), in her scrutiny of the situation of low girl enrollment in rural New Papua Guinea found traveling long distances to reach school as one of the most often appearing reasons for low enrollment of girls. Boys had access to boarding facilities, so had the option of staying backing for the entire week, but girls did not have access to such facilities. Besides, sending girls to far off places put the girls at the risk of abuse, unmarried/unwanted pregnancies or affairs with non-local men.

Poor infrastructure, particularly, quality of toilets affects girls more than boys. In a research conducted by Mensch and Lloyd (1993) in Kenya, though only $5 \%$ of girls claimed to have stayed away from school 
during their periods, but, to improve overall quality of learning at school, good quality and functional toilets and drinking water facilities are a must. The same research also found boys lurking around girls toilets. Though the research could not find a direct correlation between girl enrollment and such behavior of boys, but we can conclude that safe school environment is again an imperative to pull more girls in school.

Kirk (2006) presents the positive impact of women teachers on girls' education. There exists evidence to show correlation between number of women teachers and girls' enrollment numbers especially in SubSaharan Africa and Nepal. Oxfam (2011) in their briefing paper on girls' education in Afghanistan, state lack of women teachers as one of the obstacles to meet demand of girls' education. However, presence of women teachers and girls' enrollments should not be considered as a cause and effect as the two are dependent on many other factors.

Curriculum design, teaching styles and teacher expectations also present considerable challenges in girls' learning at school (Butler, 1991). Sadker \& Sadker (1985) confirm in their research that boys receive more attention, encouragement and airtime than girls. Though the research in this field is not directed towards rural girls but substantial derivations and scenarios can be built for understanding challenges a rural girl faces. Perhaps, this can also be an area for future research.

\section{Applying the SCCT}

The above mentioned challenges can be divided into two sets for better clarity. The first, called the demand side barriers contain barriers emerging from the girls' side, including their families. The second supply side barriers include factors emerging from provision of services by the government. The school is considered a service provided by the government (supply) and the girls' household is the receiver of this service (demand).

\section{Demand side barriers}

Grounded in literature review presented above, three main demand side barriers to girls' education emerge - (1) economic profile of the household, (2) gender role expectations prevalent in a society.
Economic conditions of a household heavily influence the demand for education for girls. Low income households are averse to sending their daughters to school due to lack of financial resources and need for daughters in completing daily chores and farm work. They consider it a loss making deal for three reasons (a) the daughter will get married and leave the natal family, hence any income arising post education will go to the new family (b) family loses out on income that could have been earned during time spent in school (c) their support in daily chores and sibling care is essential.

Lorie, Call \& Mortimer (2001) find out that, economically successful parents, who feel more efficacious themselves, also are more likely to encourage their children. This may not be directly focused on perspective of economically successful parents towards their daughters, but is enough evidence to highlight the importance of economic conditions on parents and children both. Such transfers of efficacy could perpetuate favorable location in the stratification structure across generations as well. Furthermore, parental education emerged as the strongest factor having a positive influence on girls' school enrollment chances, with mother's education being stronger of the two in a quantitative study of 600 girls in West Bengal, India (Sengupta \& Guha, 2002).Occupation also figured high in the list, in the same study. Enrollment chances were observed to be higher for girls whose fathers were employed in a white collar job and lowest for girls belonging families of agricultural labour.

Gender role expectations also play a crucial role in creating a negative demand for education for girls. Girls are expected to get married, bear children and take care of the family. The community does not see the role of education in this gender expected role of women.

\section{Supply side barriers}

Literature review on challenges/barriers to girls' education presents four supply side barriers - (1) location of the school beyond village boundaries (2) poor/no provision of clean and safe drinking water and separate toilet for girls (3) lack of boarding facilities for girls (4) non-encouraging teaching styles 
and methods (5) lack of career counseling (6) lack of role models for girls.

\section{Self-efficacy and outcome expectations}

Bandura (1977) identified four principal sources of efficacy: personal performance accomplishment, vicarious experience, verbal persuasion and physiological state. That is, people gain a sense of efficacy by observing their own successful achievements, by watching others whom they emulate, by the encouragement and reflected appraisals of others, and by judging their physiological stress levels to be low in situations involving performance demands. Self-efficacy beliefs are largely social in origin. They depend not only on one's own personal experience of success or failure, but also on one's interpretation of others' experiences and on the verbal support one receives from others in the social world.

Haller \& Portes (1973) find personal aspirations to be important indicators of female status attainment. Their study also revealed perception of low income females about their own educational and occupational futures as an important determinant of eventual achievement in life. These perceptions are formed by their parents', teachers and also community's view on their educational and occupational futures. Determinants of girls' lesser self-efficacy are thought to include unequal expectations and treatment by parents and teachers, as well as vicarious perceptions that female role models are restricted in their access to power and prestige (Lorie, Call \& Mortimer, 2001). Kfir (1988) also notes that girls of Afro-Asian ethnic group achieved and aspired more in the beginning, but a larger number regressed to lower level of aspiration during later stages of schooling.

Sources of self-efficacy for girls in rural areas are their performance in school, watching their teachers and other grown-up girls in the community and encouragement received from their families and the community. Following derivations can be made on analysis of barriers presented in the previous section:

\section{Own performance in school -}

Performance of girls in each school level starting from primary keeps decreasing. Girls tend to succeed more in primary school and less in secondary stages due to the beginning of adolescent age which requires the girls to enter into traditional sex roles (Nash, 1979). The constant decline in school performance lowers selfefficacy of girls and the confidence of others in a girls' educational and occupational attainment.

2. By watching others they emulate girls in rural areas tend to emulate grown-up women who could be their mothers, sisters and neighbours. What they find is that these grown-up girls do not go to school, work at home and farms, take care of the family, get married and bear children. These grown-up women serve as their role models.

3. Encouragement from families - Due to poor or average economic conditions of the household and gender role expectations prevalent in the society, girls tend to receive less encouragement from their immediate families to pursue educational and career pursuits in life.

A study conducted by Soares \& Soares (1969) on self-perception of culturally disadvantaged children revealed higher self-perception of disadvantaged children than the advantaged children. It further reveals that disadvantaged girls suffer from low selfperception due to son preference in middle class families. Sons are the object of affection and investment in a middle class family. Hence, girls form low self-perception about them since elementary school. Though there is equality throughout the elementary schooling stage, but secondary school is where girls start to acknowledge their role as expected by the society. These are the years when girls tend to drop-out of school as well.

\section{OUTCOME EXPECTATIONS}

Outcome expectations are concerned with beliefs around consequences of action(s). Barriers and selfefficacy have an influence in forming outcome expectations of girls in rural areas. When self- 
efficacy is low and multiple barriers exist, outcome expectations are bound to be restricted to following social norms. Kerr (1988) notes that girls are rewarded for intellectual achievement only before adolescence. By adolescence, they are rewarded for social conformity instead. Traditional gender roles, generally found in most of the rural communities, may constrain women's educational and employment options and more emphasis may be given to marriage (Jacobs et al.,1998). Even ambitious and educationally motivated girls do not have much of an option but to adopt more traditional careers or activities if they do not receive strong support from their parents (Bender, 1994).

\section{Interests, goals and actions}

Low self-efficacy and influence of traditional gender role expectations on outcome expectations result in formation of weak interests pertaining to educational or career pursuits. This, in turn, leads to traditional goal settings which results in weak actions towards pursuing education..

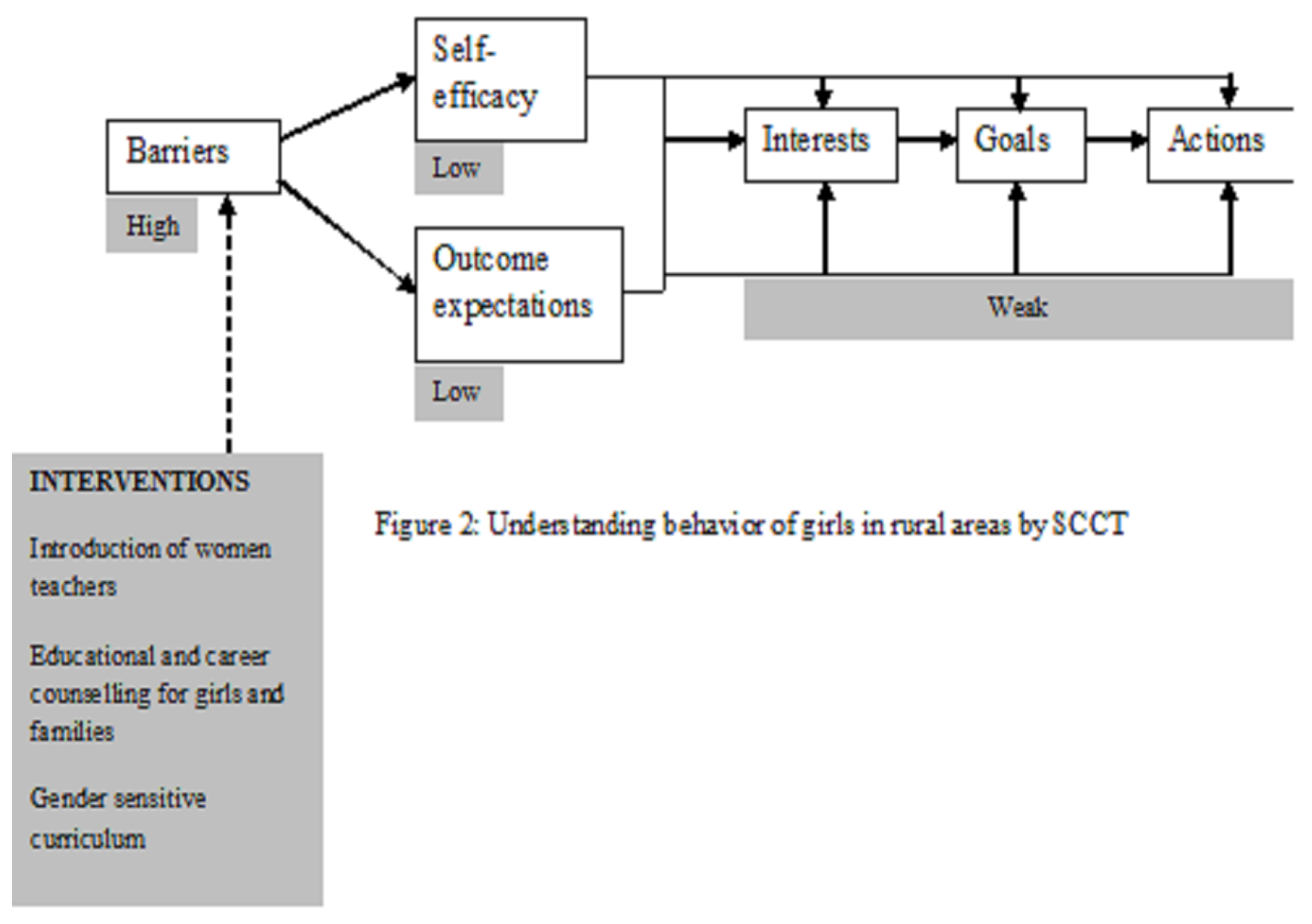

Figure 1: Understanding behavior of girls in rural areas by SCCT

\section{REFERENCES}

Bandura, A. (1977) Self-efficacy: Toward a unifying theory of behavioral change. Psychological review 84(2): 191-215.

Bandura, A. (1986). Social foundations of thought and action: A social cognitive theory. Englewood Cliffs, NJ: Prentice-Hall.
Bandura, A.. (2000). Exercise of Human Agency through Collective Efficacy. Current Directions in Psychological Science, 9(3), 75-78. Retrieved from http://www.jstor.org/stable/20182630

Bender S. (1994). Female student career aspirations in science (SSTA Research Centre Report No. 94-04, SSTA Research in Brief). Regina, Saskatchewan: Saskatchewan School Trustees Association. 
Beutel, A., \& Axinn, W. (2002). Gender, Social Change, and Educational Attainment*. Economic Development And Cultural Change, 51(1), 109-134. http://dx.doi.org/10.1086/345517

Boivin, M., \&Bégin, G.. (1989). Peer Status and SelfPerception among Early Elementary School Children: The Case of the Rejected Children. Child Development, 60(3), 591-596. http://doi.org/10.2307/1130725

Butler, D. A., \& Sperry, S.. (1991). Gender Issues and the Middle School Curriculum. Middle School Journal, 23(2), 18-23. Retrieved from http://www.jstor.org/stable/23022960

Compeau, D., Higgins, C. A., \& Huff, S.. (1999). Social Cognitive Theory and Individual Reactions to Computing Technology: A Longitudinal Study. MIS Quarterly, 23(2), 145-158.

http://doi.org/10.2307/249749

Crosnoe, R., Riegle-Crumb, C., \& Muller, C.. (2007). Gender, Self-Perception, and Academic Problems in High School. Social Problems, 54(1), 118-138. http://doi.org/10.1525/sp.2007.54.1.118

Gibbons, M. M., \&Shoffner, M. F.. (2004). Prospective First-Generation College Students: Meeting Their Needs Through Social Cognitive Career Theory. Professional School Counseling, 8(1), 91-97. Retrieved from http://www.jstor.org/stable/42732419

Lorie J. Schabo Grabowski, Call, K. T., \& Mortimer, J. T.. (2001). Global and Economic Self-Efficacy in the Educational Attainment Process. Social Psychology Quarterly, 64(2), 164-179. Retrieved from http://www.jstor.org/stable/3090131

Haller, A. O., \& Portes, A. (1973). Status attainment processes. Sociology of Education, 46, 51-91.

Hannum, E.. (2003). Poverty and Basic Education in Rural China: Villages, Households, and Girls' and Boys' Enrollment.Comparative Education Review, 47(2), 141-159. http://doi.org/10.1086/376542

Hickey, D. T.. (2003). Engaged Participation versus Marginal Nonparticipation: A Stridently Sociocultural Approach to Acheivement Motivation. The Elementary School Journal, 103(4), 401-429. Retrieved from http://www.jstor.org/stable/1002291

Jacobs, J. E., Finken, L. L., Griffin, N. L., \& Wright, J. D.. (1998). The Career Plans of Science-Talented Rural Adolescent Girls. American Educational Research Journal, 35(4), 681-704. Retrieved from http://www.jstor.org/stable/1163463

Johnson, P. L.. (1993). Education and the "New" Inequality in Papua New Guinea. Anthropology \& Education Quarterly, 24(3), 183-204. Retrieved from http://www.jstor.org/stable/3195641
Jones, M. T.. (1980). Education of Girls in Tunisia: Policy Implications of the Drive for Universal Enrollment. Comparative Education Review, 24(2), S106-S123. Retrieved from http://www.jstor.org/stable/1187557

Kerr, B. A. (1988). Raising the career aspirations of gifted girls. Vocational Guidance Quarterly, 32, 37 43.

Kfir, D.. (1988). Achievements and Aspirations among Boys and Girls in High School: A Comparison of Two Israeli Ethnic Groups.American Educational Research Journal, 25(2), 213-236. Retrieved from http://www.jstor.org/stable/1163081

Kirk, J. (2016). The Impact of Women Teachers on Girls' Education (1st ed.). Bangkok: UNESCO.

Koletsou, A., \& Mancy, R.. (2011). Which efficacy constructs for large-scale social dilemma problems? Individual and collective forms of efficacy and outcome expectancies in the context of climate change mitigation. Risk Management, 13(4), 184 208. Retrieved from http://www.jstor.org/stable/41407073

Lee, S. M., \& Smith-Adcock, S.. (2005). A Model of Girls' School Delinquency: School Bonding and Reputation. Professional School Counseling, 9(1), 78-87. Retrieved from http://www.jstor.org/stable/42732647

Lee, S. M., Daniels, M. H., Puig, A., Newgent, R. A., \& Nam, S. K.. (2008). A Data-Based Model to Predict Postsecondary Educational Attainment of Low-Socioeconomic-Status Students. Professional School Counseling, 11(5), 306-316. Retrieved from http://www.jstor.org/stable/42732839

Lent, R. W., Brown, S. D., \& Hackett, G. (1994). Toward a unifying social cognitive theory of career and academic interest, choice, and performance. Journal of Vocational Behavior, 45, 79-122.

Lent, R., Brown, S., \& Hackett, G. (2000). Contextual supports and barriers to career choice: A social cognitive analysis. Journal Of Counseling Psychology, 47(1), 36-49. http://dx.doi.org/10.1037//0022-0167.47.1.36

Lewis, M. and Lockheed, M. (2006). Inexcusable Absence. [online] Center for Global Development. Available at:

http://www.cgdev.org/sites/default/files/97819332861 43-Lewis-Lockeed-inexcusable.pdf [Accessed 15 Dec. 2014].

Lorie J. Schabo Grabowski, Call, K. T., \& Mortimer, J. T.. (2001). Global and Economic Self-Efficacy in the Educational Attainment Process. Social Psychology Quarterly, 64(2), 164-179. Retrieved from http://www.jstor.org/stable/3090131

Lu, Y., \&Treiman, D. J.. (2008). The Effect of Sibship Size on Educational Attainment in China: 
Period Variations. American Sociological Review, 73(5), 813-834. Retrieved from http://www.jstor.org/stable/25472559

Luszczynska, A. and Schwarzer, R. (2005) Socialcognitive theory. In: M. Conner and P. Norman (eds.) Predicting Health Behavior, 2nd edn. Buckingham: Open University Press, pp. 127-169.

Mare, R. D., \&Maralani, V.. (2006). The Intergenerational Effects of Changes in Women's Educational Attainments. American Sociological Review, 71(4), 542-564. Retrieved from http://www.jstor.org/stable/30039009

Mensch, B. S., \& Lloyd, C. B.. (1998). Gender Differences in the Schooling Experiences of Adolescents in Low-Income Countries: The Case of Kenya. Studies in Family Planning, 29(2), 167-184. http://doi.org/10.2307/172157

Mitchell, C., \& Yang, K. (2014).

Woman+Teacher+Rural: Bringing Gender into the Policy Framework on Teacher Deployment in Rural Areas (1st ed.). Institute for the Study of International Development.

Nash, S. C. (1979). Sex role as a mediator of intellectual functioning. In M. A. Wittig \& A. C. Peterson (Eds.), Sex-related differences in cognitive functioning (pp. 263-302). New York: Academic Press.

Oxfam,. (2011). Joint briefing paper: High stakes Girls' education in Afghanistan (1st ed.). Oxfam.

Perun, P. J., \& Bielby, D. O. (1981). Towards a model of female occupational behavior: A human development approach. Psychology of Women Quarterly, 6, 234-252.

Ross, J. A., \& Gray, P.. (2006). School Leadership and Student Achievement: The Mediating Effects of Teacher Beliefs. Canadian Journal of Education / Revue Canadienne De L'éducation, 29(3), 798-822. http://doi.org/10.2307/20054196

Rubisch, J. C.. (1995). Promoting Postsecondary Education in Rural Schools. The School Counselor, 42(5), 405-409. Retrieved from http://www.jstor.org/stable/23901015

Sadker, M.P., \& Sadker, D.M. (1985). Sexism in the school room of the 80s. Psychology Today, 88, 5457.

Sengupta, P., \& Jaba Guha. (2002). Enrolment, Dropout and Grade Completion of Girl Children in West Bengal. Economic and Political Weekly, 37(17), 1621-1637. Retrieved from http://www.jstor.org/stable/4412040

Soares, L. M., Soares, A. T., \&Pumerantz, P.. (1973). Self-Perceptions of Middle-School Pupils. The
Elementary School Journal, 73(7), 381-389. Retrieved from http://www.jstor.org/stable/1000187

Soares, A. T., \&Soares, L. M.. (1969). SelfPerceptions of Culturally Disadvantaged Children. American Educational Research Journal, 6(1), 31-45. Retrieved from http://www.jstor.org/stable/1162094

Stringer, R. W., \& Heath, N.. (2008). Academic SelfPerception and Its Relationship to Academic Performance. Canadian Journal of Education / Revue Canadienne De L'éducation, 31(2), 327-345. http://doi.org/10.2307/20466704

Tapan, S., Jha, J., Bajracharya, R., \& Mukhtar, E. (2000). Increasing the number of women teachers in rural schools : a synthesis of country case studies: South Asia. (1st ed.). Bangkok: UNESCO PROAP.

Thornton, L., \& Bergee, M.. (2008). Career Choice Influences among Music Education Students at Major Schools of Music. Bulletin of the Council for Research in Music Education, (177), 7-17. Retrieved from http://www.jstor.org/stable/40319448

Tibenderana, P. K.. (1985). The Beginnings of Girls' Education in the Native Administration Schools in Northern Nigeria, 1930-1945.The Journal of African History, 26(1), 93-109. Retrieved from http://www.jstor.org/stable/181840

Uis.unesco.org, (2015). The first stop for education data. [online] Available at:

http://www.uis.unesco.org/Education/Pages/default.as px [Accessed 12 Apr. 2015].

UNESCO,. (2001). Women Teachers in Rural India (1st ed.). New Delhi: United Nations Education,Scientific and Cultural Organization.

Unesco.org, (2015). The Right to Education | Education | United Nations Educational, Scientific and Cultural Organization. [online] Available at: http://www.unesco.org/new/en/right2education [Accessed 26 Apr. 2015].

Wilson, S. M., Peterson, G. W., \& Wilson, P.. (1993). The Process of Educational and Occupational Attainment of Adolescent Females from LowIncome, Rural Families. Journal of Marriage and Family, 55(1), 158-175. http://doi.org/10.2307/352966

Worldbank.org, (2015). The World Bank Millennium Development Goals. [online] Available at: http://www.worldbank.org/mdgs/ [Accessed 23 Dec. 2014]. 